\title{
Pollen analysis of honey samples produced in the counties of Santa Helena and Terra Roxa, Western Region of Paraná, Southern Brazil
}

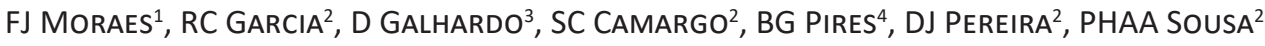 \\ 1 - University of Dynamic Falls Center, Foz do Iguaçu-PR, Brazil \\ 2 - Department of Animal Science, State University of Western Paraná, Marechal Cândido Rondon-PR, Brazil \\ 3 - Department of Animal Science, State University of Maringá, Maringá-PR, Brazil \\ 4 - Department, Entomology Department Federal University of Latin American Integration Foz do Iguaçu-PR, Brazil
}

\section{Article History \\ Edited by \\ Gilberto M. M. Santos, UEFS, Brazil \\ Received 09 August 2018 \\ Initial acceptance 02 December 2018 \\ Final acceptance 15 May 2019 \\ Publication date 20 August 2019}

\section{Keywords}

Melissopalynology; honey traceability; geographical origin.

\section{Corresponding author}

Regina Conceição Garcia

State University of Western Paraná

Department of Animal Science

Marechal Cândido Rondon, BraSil.

E-Mail: garcia.regina8@gmail.com

\begin{abstract}
Melissopalynology was used to determine the botanical origin of honey, which is important for its traceability. Forty samples of honey from the counties of Santa Helena (20) and Terra Roxa (20), the western region of Paraná, Southern Brazil, were analyzed according to the pollen types and comparisons with pollen catalogs and specialized literature. Regarding analytics quality, 300 grains of pollen per sample were identified. In the samples from Santa Helena, 71 pollen types of 24 families were found, classified as Hovenia dulcis monofloral honey (8) and the remainder as polyfloral (12). In the samples from Terra Roxa, 64 pollen types belonging to 29 families were classified as monofloral Glycine max (7), Mimosa scabrella Benth (2), Mimosa caesalpiniifolia Benth (1), Mimosa verrucosa Benth (1), Mikania (1), and Senecio (1) and as polyfloral (7). The two locations have a high similarity index; however, the predominance of some pollen types indicates the botanical specificity of the locality. For Santa Helena, a greater significance was observed for $\mathrm{H}$. dulcis pollen, Eucalyptus, Parapiptadenia rigida, and Leucaena leucocephala; in Terra Roxa, the pollen types G. max, M. scabrella, and Eucalyptus had more incidents. Despite the similarity index, the indicators show differences between the producing areas. The samples of honey from Santa Helena presented higher pollen diversity in relation to the samples of Terra Roxa, reflecting the predominant vegetative cover of riparian forests and agricultural crops, respectively, in each county.
\end{abstract}

\section{Introduction}

Honey production in Brazil has greatly evolved in recent years, with a $91 \%$ increase between the years 2000 and 2013 (Paula et al., 2015). According to Abemel (2018), Brazil is currently the ninth largest exporter of honey at approximately 37,000 tonnes. The activity is concentrated mainly in the southern region, with Paraná being one of the largest producers, being the western region responsible for 706 tonnes (IBGE, 2016), concentrating most of the production in the counties along Itaipu Lake, on the Paraná River.

The quality of honey depends on the botanical source foraging by the bees, geographical characteristics of its place of origin, climatic conditions throughout the production process, as well as processing and storage conditions. Since the Brazilian flora is highly diversified due to the country's territorial extension and climatic (edaphoclimatic) variability, it is possible to produce honey all year long with different compositions and characteristics (Marchini et al., 2004).

Some researches aim claims differ in honey according to its geographic origin. Kaškonienè and Venskutonis (2010) concluded that it is rather difficult to find reliable chemical markers for the discrimination of collected honey from different floral sources, because the chemical composition of honey also depends on several other factors, such as geographic origin, collection season, mode of storage and bee species. 
In the state of Paraná, Brazil, De Andrade et al. (2014) evaluated the relationship between geographical origin and contents of $\mathrm{Pb}, \mathrm{Cd}$, and $\mathrm{Cr}$ in honey samples, with a chemometric approach, associated with environmental pollution. Kuchla et al. (2015) classified samples of wild honey, by Principal Component Analysis (PCA). The parameters $\mathrm{pH}$, electrical conductivity and HMF were determinant for the identification of the geographic origin, on Central South, Southeast and West mesoregions. The results were attributed to the differences between the producing regions.

Bees collecting nectar to produce honey are contaminated with pollen grains, which are transferred to this product and identified through melissopalynology, indicating the botanical and geographical origin of the honey and allowing greater traceability of the product (Fagúndez et al., 2015).

In the Western region of Paraná, studies carried out with physical-chemical and pollen analyses of honey by Sekine et al. (2013), Camargo et al. (2014), Moraes et al. (2014) and Sekine et al. (2019) have characterized the region's honey. For the implementation of the Geographic Information System (GIS) by Camargo et al. (2014), 383 apiaries of 126 beekeepers were mapped in eight counties of the microregion of Toledo, characterizing the activity composed of small, medium, and large producers $(46 \%, 29 \%$, and $25 \%$, respectively), with a production representativity of $9 \%, 20 \%$, and $71 \%$, respectively.

This region presents peculiar edaphoclimatic and botanical characteristics, due to the construction of the Itaipu Binational Hydroelectric Power Plant, which caused a large area of flooding, covering 18 counties (Ostrovski, 2014). This area, called Paraná Hydrographic Basin 3 (BP3), is part of Cultivating Good Water Programme, which, so far, has promoted the planting of 44 million native and exotic seedlings; recovered Permanent Preservation Areas (Itaipu, 2017).

Since 2006, the State University of the West of Paraná (UNIOESTE) has been conducting research with characterization of the honeys of the region, in partnership with COOFAMEL - Solidarity Cooperative of Beekeepers of the West of Paraná, which collaborated for the right to use of the Indication of Provenance Seal, by the small beekeepers of the region (INPI, 2017), adding value to the honey produced by them. The demand of producers now, is for obtaining a seal of Denomination of Origin for the product, which will differentiate it by its intrinsic characteristics, related to the phytogeographic characteristics of its region of origin.

Considering that the Western region of Paraná has specific phytogeographic characteristics and representative honey production, this research aimed the melissopalynological characterization and calculation of similarity among Apis mellifera L., 1758 honey samples from counties of Santa Helena and Terra Roxa, located in this same region.

\section{Material and Methods}

We analyzed 40 samples of $A$. mellifera honey from the 2008/2009 harvest, provided by beekeepers associated with the Beekeeping Cooperative of the West of Paraná (COOFAMEL), including 20 samples from Santa Helena and 20 samples from Terra Roxa.

Both studied counties are part of the Paraná basin, located in the Western mesoregion of Paraná, between latitudes $24^{\circ} 01^{\prime} \mathrm{S}$ and $25^{\circ} 35^{\prime} \mathrm{S}$ and longitudes $53^{\circ} 26^{\prime} \mathrm{W}$ and $54^{\circ}$ $37^{\prime}$ W (Fig 1). The Paraná River runs through the damming region of the Itaipu hydroelectric power plant. A reforestation

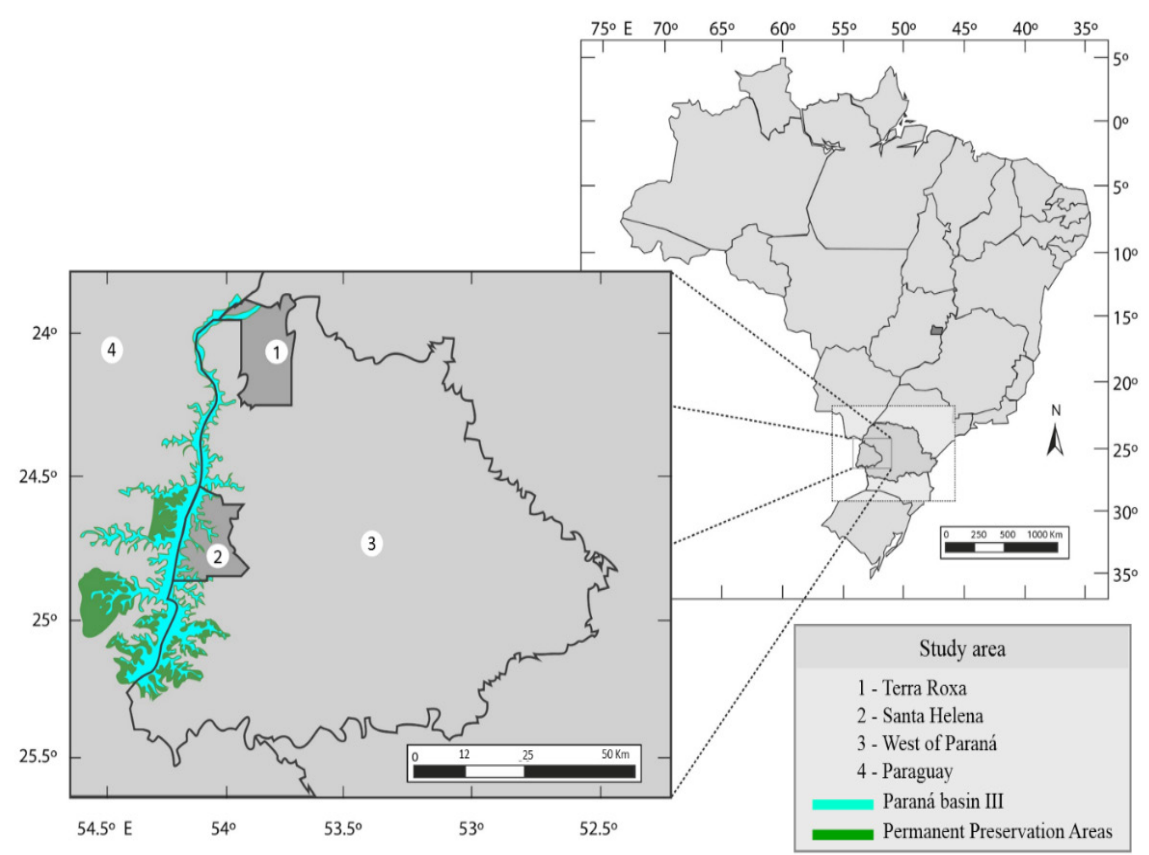

Fig 1. Location map showing the study area. (right) map showing the position of Paraná State in Brazil, (Left) map showing the sampling counties in the region west of Paraná State, as well as the Paraná River Basin III, which borders Paraguay. 
area, along the lake, is called the green belt, due to its $200-\mathrm{m}$ width (Ostrovski, 2014; Itaipu, 2017).

Santa Helena is located on the banks of Itaipu Lake, covers $184 \mathrm{~km}^{2}$ of Itaipu Lake area, of which approximately 80 $\mathrm{km}$ is riparian forest; it has altitude of $258 \mathrm{~m}$, latitude $24^{\circ} 51^{\prime}$, $37^{\prime \prime} \mathrm{S}$, longitude $54^{\circ} 19^{\prime} 58^{\prime}$ 'W-GR, and total area of $754.7 \mathrm{~km}^{2}$.

The county of Terra Roxa is located in a straight line, $18.27 \mathrm{~km}$ from Itaipu Lake, with an altitude of $260 \mathrm{~m}$ and a total area of $845.38 \mathrm{~km}^{2}$ (latitude $24^{\circ} 09^{\prime} 40^{\prime \prime} \mathrm{S}$ and longitude $\left.54^{\circ} 06^{\prime} 30^{\prime \prime} \mathrm{W}-\mathrm{GR}\right)$. The county does not border Itaipu Lake, so the vegetation characteristics are distinct in relation to Santa Helena. The county is characterized by agriculture centered on the wheat and soybean, highly mechanized and with use of inputs (Willers et al., 2010).

According to Köppen (1948), the climate of the region is classified as Cfa: humid subtropical mesothermic, hot summers with a tendency for rainfall concentration, winter with infrequent frost (average temperature below $18{ }^{\circ} \mathrm{C}$ ), and no defined dry season. The average annual temperature is approximately $22{ }^{\circ} \mathrm{C}$, with the highest monthly average values concentrated in January and February at around $28^{\circ} \mathrm{C}$. The colder periods are concentrated in the months of June, July, and August, with average monthly minimum temperatures around $18^{\circ} \mathrm{C}$.

The average annual rainfall is $1.700 \mathrm{~mm}$, with the lowest values in June, July, and August, with an average of $287 \mathrm{~mm}$. The rainy months are December, January, and February, with average precipitation of $450 \mathrm{~mm}$. The soil from the region is composed of eutrophic purple latosol (45\%), eutrophic structured purple earth (45\%), and eutrophic lithographic solos soils (10\%) (Embrapa, 2006).

\section{Melissopalynological analyses}

For the identification and quantification of the pollen grains present in honey samples, we used the methodology of acetolysis (Erdtman, 1960), recommended by the International Commission for the Botanical Determination of Honey (Louveaux et al., 1978), which allows its identification with more precision (Martins et al., 2011; Osterkamp \& Jasper, 2013).

To determine the degree of importance of the botanical origin in the honey constitution, we used the classification given by the count of 300 pollen grains per sample (Behm et al., 1996). The pollen types were classified in four classes of frequency (Louveaux et al., 1978, Barth, 1989): dominant pollen (D) ( $>45 \%$ of the total grains in the sample), accessory pollen (A) (16-45\%), important isolated pollen (I) (3-15\%), occasional isolated pollen $(\mathrm{O})(<3 \%)$, and unidentified $(\mathrm{NI})$ pollen. Samples with pollen grain frequencies of a given plant, above $45 \%$ in the samples, were considered as monofloral.

The identification of the pollen grains was carried out by consulting the specialized literature and comparing them with pollen collection slides from the Department of Entomology and Acarology of the College of Agriculture Luiz de Queiroz (ESALQ/USP), with the help of Augusta C.C.C. Moreti.

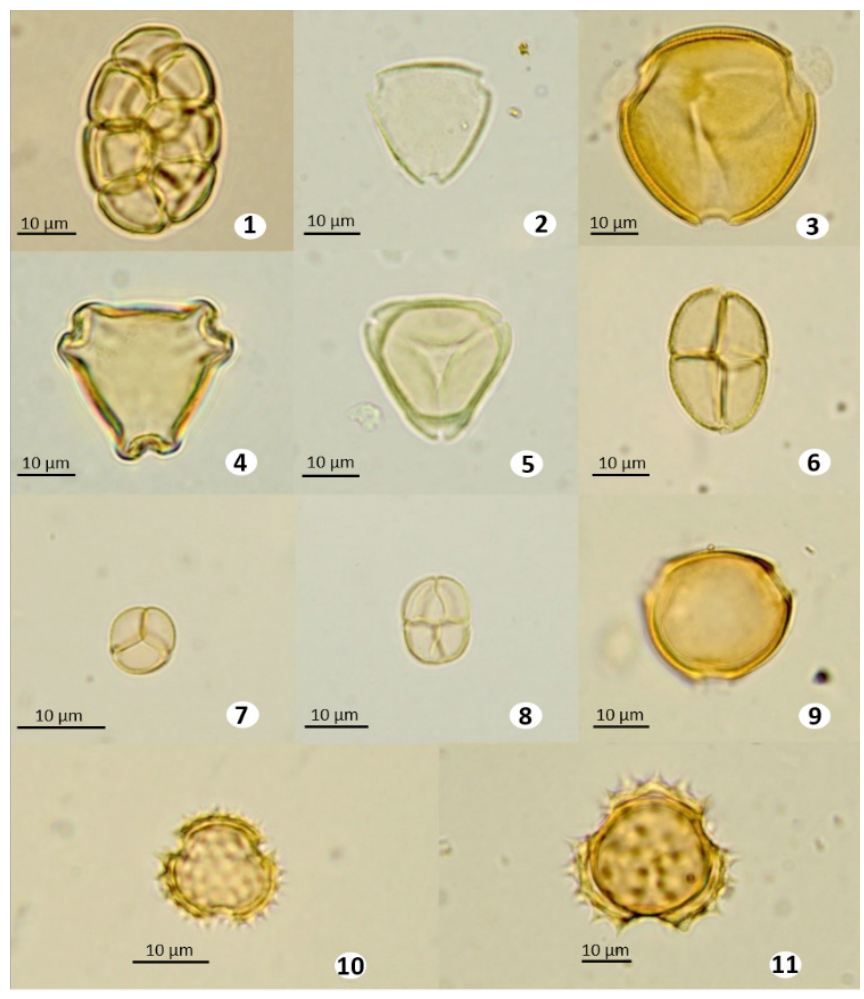

Fig 2. Principal pollen types found in honey samples of $A$. mellifera from Santa Helena and Terra Roxa, PR, 2008/2009 harvest: 1Parapiptadenia rigida (Leguminosae-Caesalpinioideae); 2- Myrcia type (Myrtaceace); 3- Leucaena leucocephala (LeguminosaeCaesalpinioideae); 4- Hovenia dulcis (Rhamnaceae); 5- Eucalyptus (Myrtaceae); 6- Mimosa verrucosa (Leguminosae-Caesalpinioideae); 7- Mimosa scabrella (Leguminosae-Caesalpinioideae); 8- Mimosa caesalpiniifolia; 9- Glycine max (Leguminosae); 10- Mikania (Asteraceae); 11-Senecio (Asteraceae).

\section{Statistical analyses}

According to the frequency of the pollen types found in the samples of the two studied localities, Sorensen's similarity coefficient (Legendre \& Legendre, 1984) was calculated using the following formula: ISS $=2 c /(a+b+c) \times 100$, where: $a)$ number of species restricted to area $a$; $b$ ) number of species restricted to area $b$; c) number of species common to areas a and $b$. This coefficient indicates the pollen types common to both localities.

The mean, expressed as the percentage of pollen types identified in total samples, for each county, was calculated, indicating which are the most representative (Table 3). With the frequencies of the pollen types found in each sample of each county, a bipartite interaction network was created between the pollen types and the honey samples, using the bipartite software package R (2014), observed in Figure 3. This software generated the calculation of the Shannon Specialization Index (H2') according to the following formula:

$$
H_{2}{ }^{\prime}=\frac{H_{2 \max }-H_{2}}{H_{2 \max }-H_{2 \min }} H_{2}{ }^{\prime}=\frac{H_{2 \max }-H_{2}}{H_{2 \max }-H_{2 \min }} .
$$

The result varies between 0 (minimum specialization or maximum generalization) and 1 (maximum specialization or 
minimum generalization). The pollen frequency in each sample was used to determine other ecological parameters (Table 4).

The Shannon-Weaver Diversity Index (H'), to determine the diversity in ${ }_{s}$ each sample, was obtained by the following formula: $\mathrm{H}^{\prime}=\sum_{i=l}^{s} \dot{p} \mathrm{~h} \dot{p}$,

Table 1. Pollen types and frequency classes of: Santa Helena honey samples, where: D: dominant pollen ( $>45 \%)$; A: accessory pollen (15-45\%); I: important isolated pollen (3-5\%); O: occasional isolated pollen $(<3 \%)$; NI: not identified.

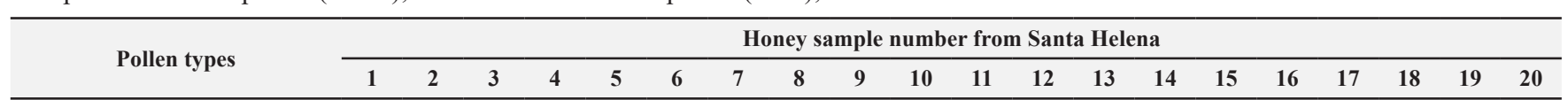

\section{Amaranthaceae}

Alternanthera tenella
Amaranthus

Chamssoa

Tapirira

Manguifera índica

Schinus

NI

Apocynaceae

NI

Araceae

NI

Anthurium

O

O

I

Arecaceae

Astrocaryum

Palmae

Ambrosia

Bidens

Helianthus annuus

Asteraceae

Mikania

Pluchea

Senecio

Sonchus

Tithonia

Vernonia

Bignoniaceae

NI

Bignoniaceae

Tabebuia

Boraginaceae

Cordia Trichotoma

Brassicaceae

Raphanus

Raphanus sativus

Caesalpiniaceae

NI

Bauhinia

Delonix regia

Peltophoroides

Euphorbiaceae

NI

Alchornea

A

O O O

I

O

O

I O

$\mathrm{O}$

$\mathrm{O}$
$\mathrm{O}$

$\mathrm{O} \quad \mathrm{O}$

$\mathrm{O}$

$\mathrm{O} \quad \mathrm{I}$

I

O I
$\mathrm{O}$

I

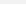

where H': Shannon-Weaver Diversity Index; $S$ : number of species (species richness); and $p i$ : ratio species $i$, estimated as ni/ $\mathrm{N}$, where in is the number of individuals, $\mathrm{N}$ is the total number of individuals (pollen grains), and $\ln$ is the natural logarithm (Shannon \& Weaver, 1949; Song et al., 2012). 
Table 1. Pollen types and frequency classes of: Santa Helena honey samples, where: D: dominant pollen ( $>45 \%)$; A: accessory pollen (15-45\%); I: important isolated pollen (3-5\%); O: occasional isolated pollen $(<3 \%)$; NI: not identified. (Continuation)

\begin{tabular}{|c|c|c|c|c|c|c|c|c|c|c|c|c|c|c|c|c|c|c|c|c|}
\hline \multirow{2}{*}{ Pollen types } & \multicolumn{20}{|c|}{ Honey sample number from Santa Helena } \\
\hline & 1 & 2 & 3 & 4 & 5 & 6 & 7 & 8 & 9 & 10 & 11 & 12 & 13 & 14 & 15 & 16 & 17 & 18 & 19 & 20 \\
\hline \multicolumn{21}{|l|}{ Leguminosae (Continuation) } \\
\hline NI 2 & & & & & & & & & & & & & & & I & & & & & $\mathrm{O}$ \\
\hline NI 3 & & & & & & & & & & & & & & & $\mathrm{O}$ & & & & & \\
\hline Calopogonium & & & & & $\mathrm{O}$ & & & & & & & & & & & & & & & \\
\hline Desmodium & & & & & & & & & & & & & & & & & & & & I \\
\hline Glycine $\max$ & I & I & & & A & & & A & $\mathrm{O}$ & & & & $\mathrm{O}$ & I & I & & $\mathrm{O}$ & $\mathrm{O}$ & & I \\
\hline Machaerium & & & & & & & & & & & & & & & & & & & I & \\
\hline Senna & & & & & & & & & $\mathrm{O}$ & & & & & & & & & & & \\
\hline Stenolobium & & & & & & & & & & & & & I & & & & & & & \\
\hline \multicolumn{21}{|l|}{ Lamiaceae } \\
\hline Leonurus & & & & & & & & & & & & & & & & & $\mathrm{O}$ & & & \\
\hline \multicolumn{21}{|l|}{ Leguminosae-Caesalpinioideae } \\
\hline Tipo Acacia & & & & & $\mathrm{O}$ & & I & $\mathrm{O}$ & & & I & & $\mathrm{O}$ & I & $\mathrm{O}$ & $\mathrm{O}$ & & I & & I \\
\hline Entada & & & & & & & & & & & & & & & $\mathrm{O}$ & & & & $\mathrm{O}$ & \\
\hline Leucaena. & & & & & & & & & & & & & & & & $\mathrm{O}$ & $\mathrm{O}$ & & & \\
\hline Leucaena leucocephala & I & $\mathrm{O}$ & I & $\mathrm{O}$ & $\mathrm{O}$ & $\mathrm{O}$ & & $\mathrm{O}$ & I & I & $\mathrm{O}$ & A & A & I & $\mathrm{O}$ & I & A & $\mathrm{O}$ & $\mathrm{O}$ & \\
\hline Mimosa caesalpiniifolia & I & & & & & & & & $\mathrm{O}$ & & $\mathrm{O}$ & & & $\mathrm{O}$ & & & & & & \\
\hline Mimosa scabrella & & & & & & & & & & & & & & & & & $\mathrm{O}$ & & & \\
\hline Leguminosae-Caesalpinioideae & & & & & & & & & & & & & & & & & & & I & \\
\hline Parapiptadenia rigida & A & I & I & I & I & I & I & A & I & $\mathrm{O}$ & I & $\mathrm{O}$ & $\mathrm{O}$ & I & $\mathrm{O}$ & I & $\mathrm{O}$ & $\mathrm{O}$ & I & I \\
\hline Morus alba & & & & & $\mathrm{O}$ & & & & $\mathrm{O}$ & $\mathrm{O}$ & & & & $\mathrm{O}$ & $\mathrm{O}$ & $\mathrm{O}$ & & & & \\
\hline \multicolumn{21}{|l|}{ Malvaceae } \\
\hline Malvastrum & & $\mathrm{O}$ & & & & & & & & & & & & & & & & & & \\
\hline \multicolumn{21}{|l|}{ Melastomataceae } \\
\hline Miconia & & & & & & & & & & & & & & & & $\mathrm{O}$ & & & & $\mathrm{O}$ \\
\hline Tibouchina & & & & & I & & & & & & & & & & & & & & & \\
\hline \multicolumn{21}{|l|}{ Myrtaceae } \\
\hline Eucalyptus & $\mathrm{O}$ & I & I & $\mathrm{O}$ & A & A & A & I & I & I & A & I & I & A & A & $\mathrm{O}$ & I & $\mathrm{O}$ & I & I \\
\hline Eucalyptus & & & & & & & & & & & & & & & & & $\mathrm{O}$ & & & \\
\hline type Myrcia & & I & & A & $\mathrm{O}$ & I & I & $\mathrm{O}$ & I & $\mathrm{O}$ & I & $\mathrm{O}$ & I & $\mathrm{O}$ & I & $\mathrm{O}$ & $\mathrm{O}$ & $\mathrm{O}$ & & $\mathrm{O}$ \\
\hline \multicolumn{21}{|l|}{ Oleaceae } \\
\hline Ligustrum & & $\mathrm{O}$ & & & & & & & & & & & & & & & & & & \\
\hline \multicolumn{21}{|l|}{ Piperaceae } \\
\hline Piper & & & & & & & & & & & & & & & & & $\mathrm{O}$ & $\mathrm{O}$ & & \\
\hline \multicolumn{21}{|l|}{ Polygonaceae } \\
\hline Antigonon cordatum & & & & & & & & & & & & & & & & & $\mathrm{O}$ & & & \\
\hline Polygonum & & & & & & & & & & & & & & & & & & & $\mathrm{O}$ & \\
\hline \multicolumn{21}{|l|}{ Polypodiaceae } \\
\hline NI & & & & $\mathrm{O}$ & & & & & & & & & & & & & & & & \\
\hline \multicolumn{21}{|l|}{ Rhamnaceae } \\
\hline Hovenia dulcis & I & $\mathrm{D}$ & $\mathrm{D}$ & $\mathrm{D}$ & I & $\mathrm{D}$ & $\mathrm{O}$ & A & A & $\mathrm{D}$ & A & A & A & I & & $\mathrm{D}$ & A & $\mathrm{D}$ & A & $\mathrm{D}$ \\
\hline Rutaceae & & & & & & & & & & & & & & & & & & & & \\
\hline Citrus & & & & & $\mathrm{O}$ & & & & & & & & & & $\mathrm{O}$ & & & & & \\
\hline Zanthoxylum & & & & & & & & & & & & & & & A & I & & & & \\
\hline Sapindaceae & & & & & & & & & & & & & & & & & & & & \\
\hline Paullinia & I & & & & & & & & & & & & & & & & & & & \\
\hline Serjania & & & & & & & & & & $\mathrm{O}$ & & & & & & & $\mathrm{O}$ & & & \\
\hline Solanaceae & & & & & & & & & & & & & & & & & & & & \\
\hline NI & & & & & I & & & I & & I & I & I & $\mathrm{O}$ & & & $\mathrm{O}$ & & & & \\
\hline NI & $\mathrm{O}$ & & & & & & $\mathrm{O}$ & & & & & & & & & & & & & \\
\hline
\end{tabular}


In order to verify the degree of uniformity of types pollen, according to the distribution of the number of pollen grains of each pollen type, in each sample, we used the Pielou Evenness Index (J'). Mathematically it is defined as a diversity index, with the following formula: $\mathrm{J}^{\prime}=\mathrm{H}^{\prime}$ (observed) $/ \mathrm{H}^{\prime}$ Maximum, where H' Maximum is the maximum possible diversity that can be observed if all species (pollen types) have equal abundance, and H' Maximum $=\log \mathrm{S}$, where $\mathrm{S}=$ total number of pollen types (richness). The value of J' ranges from 0 to 1 , according to the heterogeneous or homogeneous presence of the pollen types (Pielou, 1966; 1975). It would be 1, if the numbers of pollen grains were the same for all pollen types found, and 0 if there was a single dominant pollen type. Data were analyzed using the statistical program Paleontological Statistics (PAST), version 1.89b (Hammer et al., 2008).

\section{Results}

A total of 69 pollen types belonging to 27 families, and two unidentified ones, were characterized in the 20 samples of $A$. mellifera honey analyzed in Santa Helena. The families with the highest numbers of pollen types represented in the honey samples were Asteraceae (9), Leguminosae (9), and Leguminosae-Caesalpinioideae (8). The predominant pollen types in the samples were P. rigida (Leguminosae-Caesalpinioideae) and Eucalyptus. (Myrtaceae), which were present in all samples; H. dulcis (Rhamnaceae) and L. leucocephala (LeguminosaeCaesalpinioideae), present in 19 and 18 samples, respectively; and Myrcia (Myrtaceae), found in 17 samples.

Considering the individual samples, $H$. dulcis (Rhamnaceae) appears as the dominant pollen type (D) in $40 \%$ (8) of the samples, which were classified as monofloral;

Table 2. Pollen types and frequency classes of: Terra Roxa honey sampless, where: D: dominant pollen (> 45\%); A: accessory pollen (15-45\%); I: important isolated pollen (3-5\%); O: occasional isolated pollen $(<3 \%)$; NI: not identified.

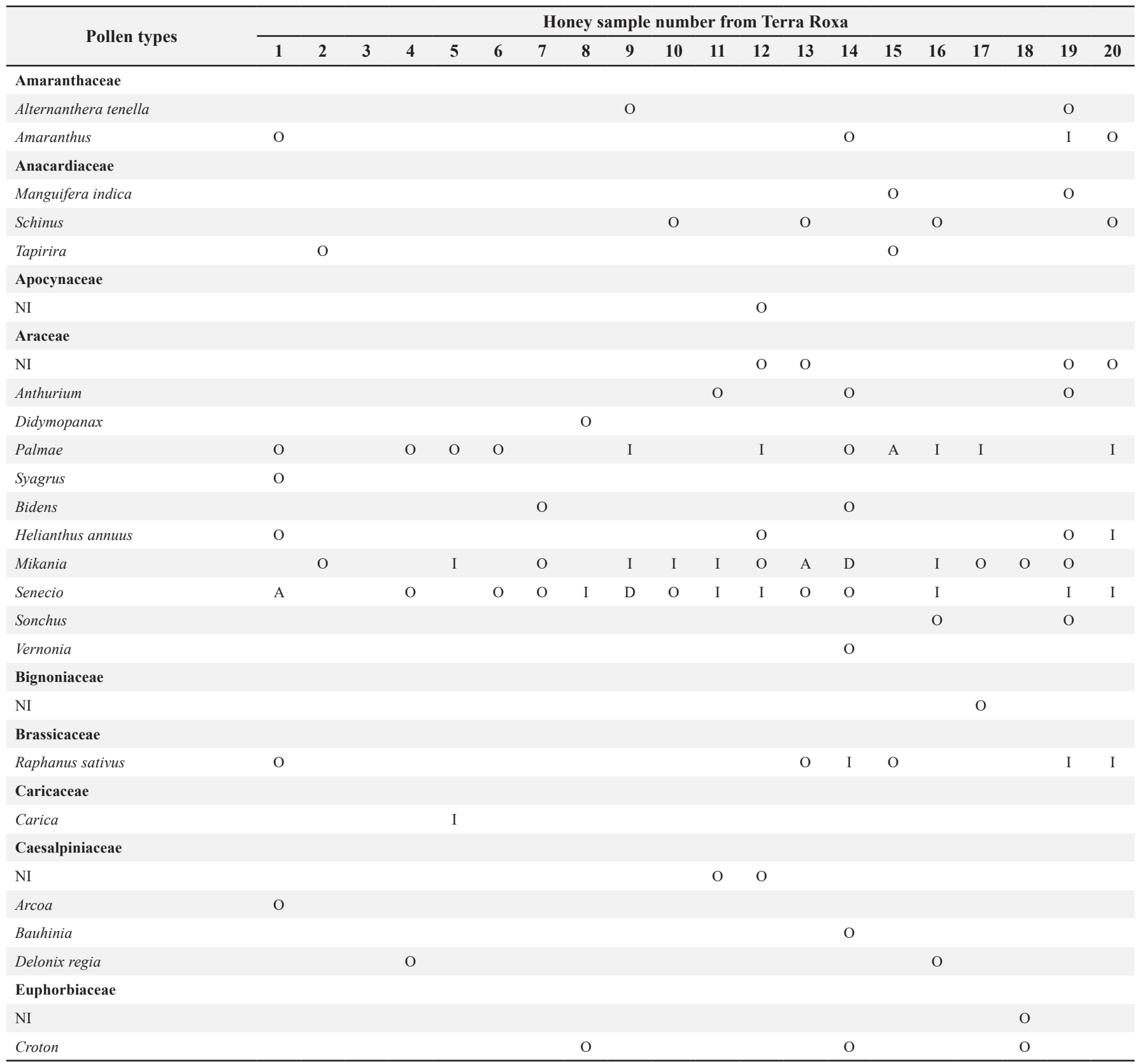


Table 2. Pollen types and frequency classes of: Terra Roxa honey sampless, where: D: dominant pollen ( $>45 \%)$; A: accessory pollen (15-45\%); I: important isolated pollen (3-5\%); O: occasional isolated pollen $(<3 \%)$; NI: not identified. (Continuation)

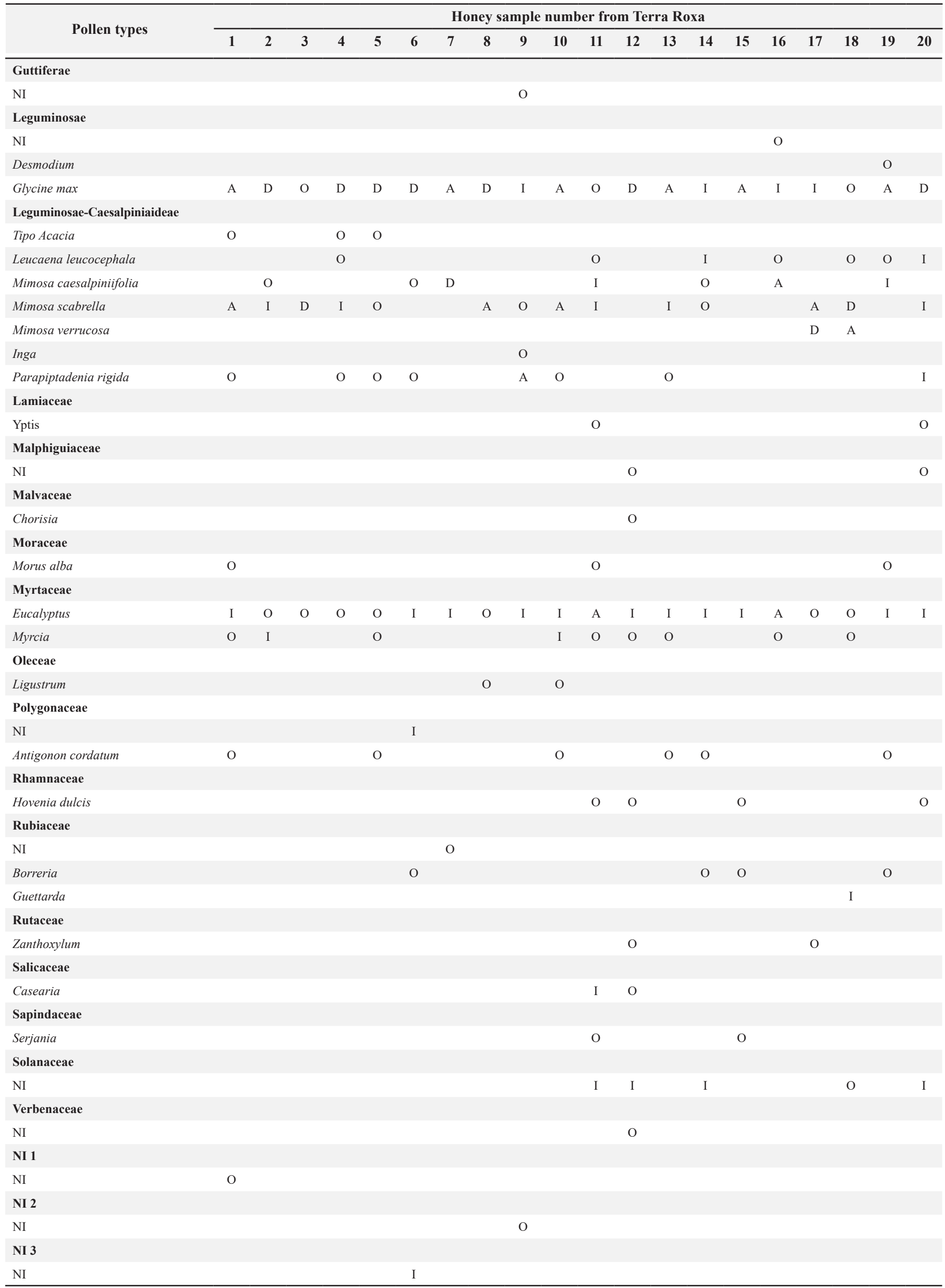


the others $(60 \%)$ were classified as polyfloral. Accessory pollen grains (A) were found for Senecio (Asteraceae), P. rigida (Leguminosae-Caesalpinioideae), Myrcia type (Myrtaceae), Eucalyptus. (Myrtaceae), G. max (Leguminosae), L. leucocephala (Leguminosae-Caesalpinioideae), Zanthoxylum (Rutaceae), and Palmae type (Arecaceae). There were 92 occurrences classified as important isolated pollen (I), belonging to 31 pollen types, and 147 occurrences of occasional isolated pollen $(\mathrm{O})$, derived from 61 pollen types.

In the 20 samples from Terra Roxa, 57 pollen types belonging to 29 plant families and four unidentified pollen types were found (Table 2). The families LeguminosaeCaesalpinioideae (7), Asteraceae (6), and Leguminosae (5) represented the highest percentage in the samples. The most frequent pollen types were G. $\max$ (Leguminosae) and Eucalyptus (Myrtaceae), which were present in the 20 samples, followed by Senecio. (Asteraceae) and M. scabrella (Leguminosae-Caesalpinioideae), found in 14 samples, and Myrcia type (Myrtaceae) and Mikania (Asteraceae) in 13 samples.

Considering the samples individually, G. $\max$ (Leguminosae) was present as the dominant pollen type (D) in seven samples (35\%); M. scabrella (LeguminosaeCaesalpinioideae) in two; and M. caesalpiniifolia, Mimosa verrucosa (Leguminosae-Caesalpinioideae), Mikania (Asteraceae), and Senecio. (Asteraceae) in one. These samples are classified as monofloral, and the remaining seven are classified as polyfloral. We observed 62 important isolated pollen types (I), belonging to 19 pollen types, and 136 occurrences of isolated pollen $(\mathrm{O})$, derived from 53 pollen types.

The presence of the different pollen grains in each sample from each county and the importance of each botanical species in the honey samples of these counties, can be observed in Figure 3, through the network bipartite interaction between pollen types present in each sample from Santa Helena and Terra Roxa. The percentage of pollen types identified for each county are showed in Table 3.

Table 3. Percentage of the main pollen types occurring in total samples of honey from Santa Helena and Terra Roxa (PR), 2008/2009 harvest.

\begin{tabular}{lcc}
\hline \multirow{2}{*}{ Pollen Type } & \multicolumn{2}{c}{ County } \\
\cline { 2 - 3 } & Santa Helena (\%) & Terra Roxa (\%) \\
\hline Hovenia dulcis & 38.68 & 0.10 \\
Eucalyptus & 12.55 & 7.74 \\
Parapiptadenia rigida & 8.00 & 1.54 \\
Leucaena leucocephala & 6.99 & 0.85 \\
Glycine max & 4.20 & 36.55 \\
Mimosa caesalpiniifolia & 0.31 & 5.14 \\
Mikania & 0.12 & 7.04 \\
Mimosa scabrella & 0.02 & 15.46 \\
Others & 29.13 & 25.58 \\
\hline
\end{tabular}

The values of the specialization index (H2') of the two split networks (A and B) were 0.33 and 0.46 , respectively. The Sorensen Similarity Coeficient (ISS), calculated among the honey samples of the counties in relation to the present flora, was $87.23 \%$. The richness (S) and diversity ( $\left.\mathrm{H}^{\prime}\right)$, and evenness (J') indexes calculated for the pollen types found in the honey samples of the studied counties can be observed in Table 4 .

Table 4. Number or richness (S), and diversity ( $\left.\mathrm{H}^{\prime}\right)$, and evenness $(\mathrm{J}$ ') indexes of the pollen types found in each honey sample from the counties from Santa Helena and Terra Roxa, PR.

\begin{tabular}{|c|c|c|c|c|c|c|}
\hline \multirow{2}{*}{$\begin{array}{l}\text { Sample } \\
\text { number }\end{array}$} & \multicolumn{3}{|c|}{ Santa Helena } & \multicolumn{3}{|c|}{ Terra Roxa } \\
\hline & $(S)$ & $\left(H^{\prime}\right)$ & $\left(J^{\prime}\right)$ & $(S)$ & $\left(H^{\prime}\right)$ & $\overline{\left(J^{\prime}\right)}$ \\
\hline 1 & 9 & 1.77 & 0.81 & 11 & 1.67 & 0.69 \\
\hline 2 & 13 & 1.85 & 0.72 & 6 & 0.61 & 0.34 \\
\hline 3 & 6 & 0.83 & 0.46 & 3 & 0.11 & 0.10 \\
\hline 4 & 9 & 1.32 & 0.60 & 8 & 0.72 & 0.34 \\
\hline 5 & 18 & 2.38 & 0.82 & 10 & 0.95 & 0.41 \\
\hline 6 & 7 & 1.02 & 0.52 & 9 & 0.93 & 0.42 \\
\hline 7 & 8 & 1.57 & 0.75 & 5 & 1.00 & 0.62 \\
\hline 8 & 12 & 2.12 & 0.85 & 7 & 0.89 & 0.46 \\
\hline 9 & 17 & 2.41 & 0.85 & 10 & 1.55 & 0.67 \\
\hline 10 & 11 & 1.80 & 0.75 & 10 & 1.65 & 0.71 \\
\hline 11 & 13 & 1.94 & 0.75 & 16 & 2.25 & 0.81 \\
\hline 12 & 10 & 1.67 & 0.73 & 17 & 1.76 & 0.62 \\
\hline 13 & 12 & 1.85 & 0.74 & 11 & 1.69 & 0.70 \\
\hline 14 & 20 & 2.24 & 0.75 & 18 & 1.97 & 0.68 \\
\hline 15 & 14 & 2.01 & 0.75 & 9 & 1.78 & 0.81 \\
\hline 16 & 13 & 1.63 & 0.63 & 12 & 1.66 & 0.72 \\
\hline 17 & 18 & 1.88 & 0.65 & 8 & 1.26 & 0.60 \\
\hline 18 & 10 & 1.33 & 0.57 & 11 & 1.16 & 0.48 \\
\hline 19 & 15 & 2.16 & 0.79 & 17 & 2.01 & 0.71 \\
\hline 20 & 15 & 1.78 & 0.65 & 16 & 1.95 & 0.70 \\
\hline Average & 12.5 & 1.78 & 0.71 & 10.7 & 1.38 & 0.58 \\
\hline
\end{tabular}

\section{Discussion}

The present study provides new insights into the pollen composition of honey samples produced by A. mellifera bees in the counties of Santa Helena and Terra Roxa, in Western region of Paraná.

The profile of the pollen spectrum determined in the study indicated predominance of the families Asteraceae, Leguminosae, and Leguminosae-Caesalpinioideae, presenting a great diversity of botanical species. Sekine et al. (2013) also observed the predominance of the Asteraceae in honey samples from others counties of the Western region of Parana, as well as of the Myrtaceae, and Solanaceae.

In this study, it was observed that $40 \%$ of the Santa Helena honey samples presented H. dulcis (Rhamnaceae) as dominant pollen and this pollen type was present in $95 \%$ of the 
samples. In 35\% of the Terra Roxa samples G. max showed as dominant pollen, and was present in all samples. The pollen type Eucalyptus was observed in all samples of both counties (Table 1 and 2). Sekine et al. (2013) observed in the analyzed honey samples from two predominantly agricultural counties, that $47 \%$ of the samples present dominant pollen G. max, Eucalyptus, Machaerium stipitaum, Brassicaceae, Melia azedorach and $P$. rigida. However, more than $50 \%$ of the pollen types found were

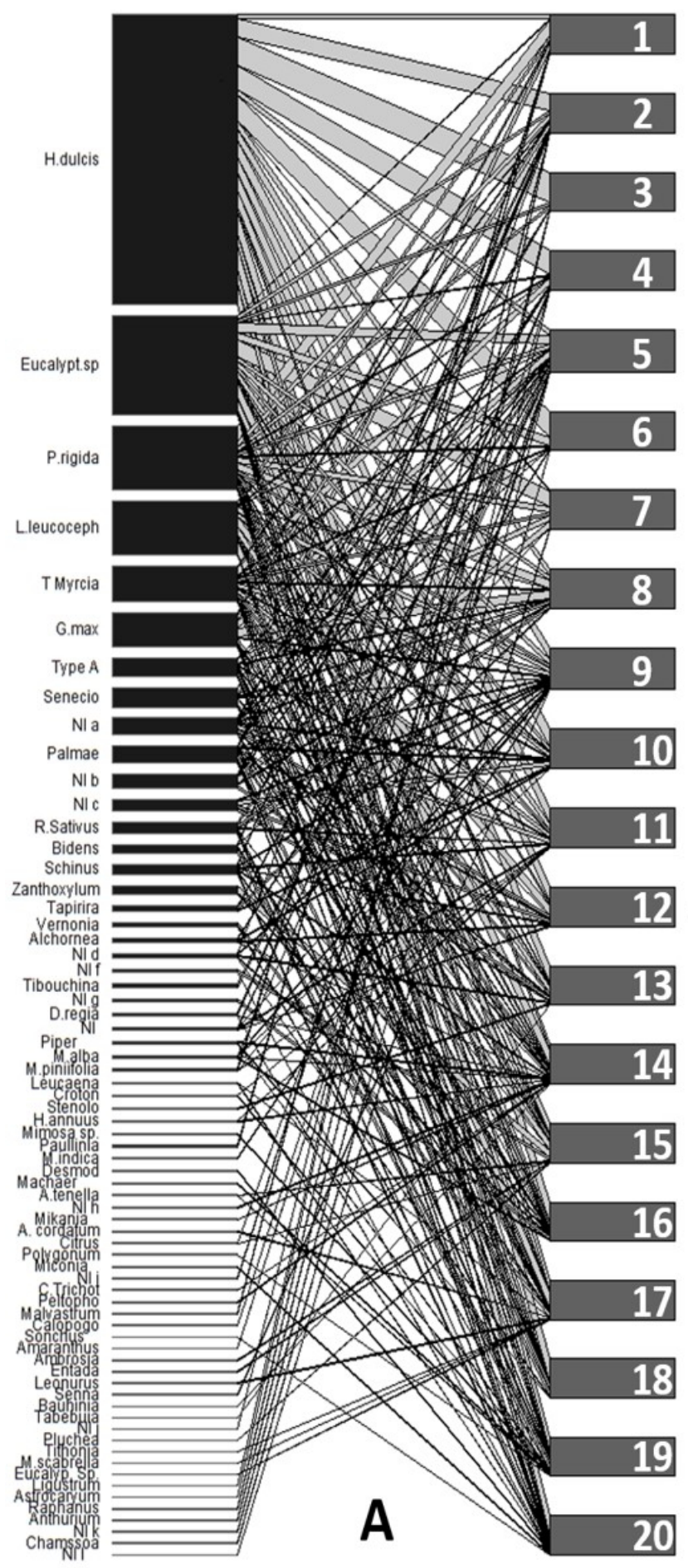

of native species, such as Schinus terebinthifolius, Baccharis, P. rigida, Hexaclamys edulis, and Serjania.

The use of bipartite matrices (Figure 3) demonstrated the importance of certain pollen types, allowing visualization and evaluation of the distribution of the different species in each honey sample. The results indicated that the type pollen of H. dulcis, Eucalyptus, P. rigida, and L. leucocephala were more frequent in the Santa Helena samples, while the Terra

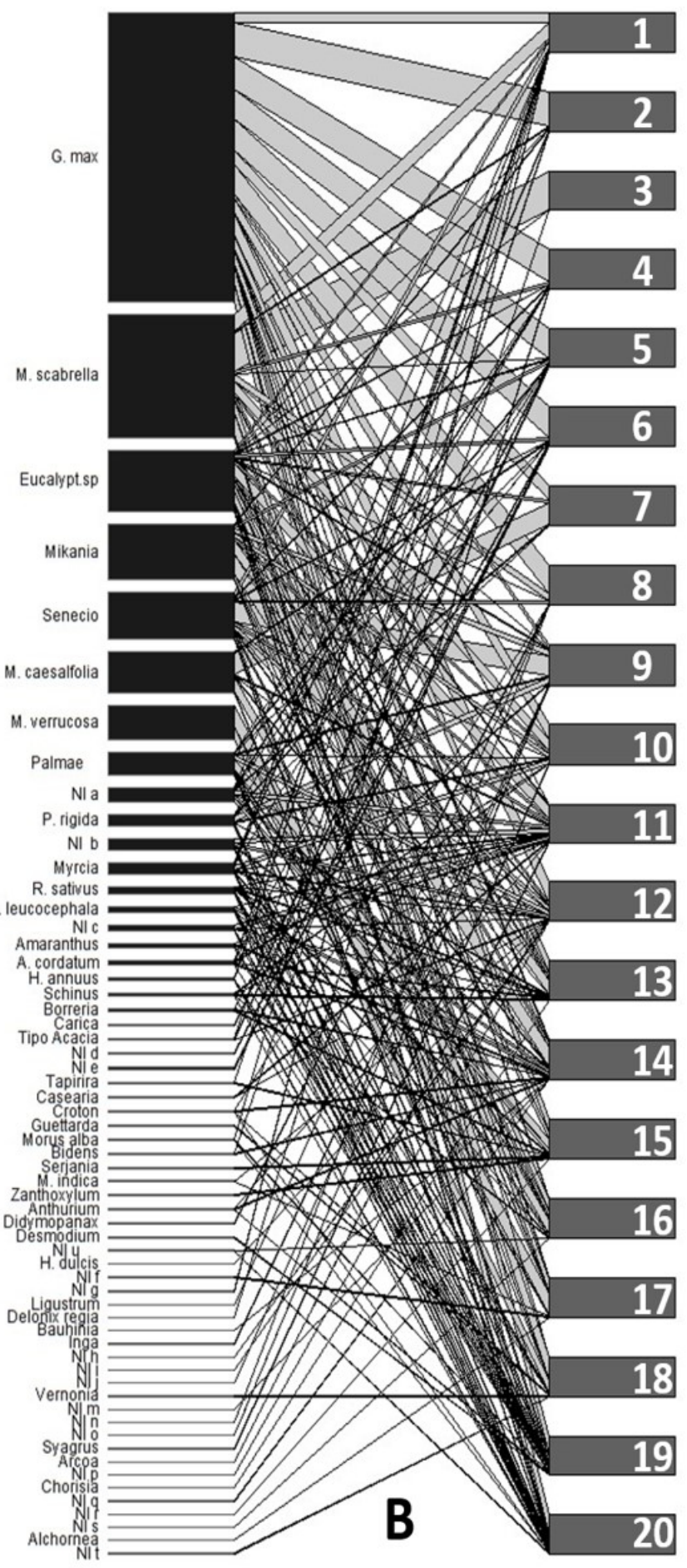

Fig 3. Quantitative bipartite network among pollen types identified in different honey samples. The binary matrix (A) represents the honey samples from Santa Helena and (B) samples of honey collected in Terra Roxa. Each black rectangle represents species of plants (left) and samples of honey from the counties (right). The lines between the columns indicate the number of pollen types in each sample, and the width of each rectangle on the left indicates the pollen frequency in all samples. 
Roxa ones showed a higher amount of type pollen of G. max, M. scabrella, Eucalyptus, and Mikania (Table 3). Apparently, the matrices behave in equal ways, with the diversity of some botanical species and predominance of others, according to the predominant type of vegetation cover of each study area, riparian forests or agriculture.

Qualitative analyses of the pollen types in the Santa Helena and Terra Roxa honey samples, revealed 69 and 57 pollen types (richness), respectively (Table 1). The presence of a greater number of pollen types in the samples of honey from Santa Helena, confirms a greater diversity of apicultural plants in this county in relation to Terra Roxa (Figure 3).

Ramírez-Arriaga et al. (2011) observed great variation in the diversity of pollen types in samples of honey collected in four districts of the State of Oaxaca, Mexico. Estevinho et al. (2016) carried out an association of multivariate statistical techniques with physico-chemical, melissopalynological and phenolic components analyzes of 112 samples of monofloral honey from Lavandula from different regions of Portugal. They concluded that the presence of different pollen types, in small quantities, influenced the amount of phenolic compounds in the samples.

The relatively higher value of the Shannon-Weaver Diversity Index (H': 1.78 and 1.38) of pollen types in Santa Helena samples in relation to Terra Roxa samples (Table 4), respectively, also suggests a great diversity of species used in the reforestation of riparian forests, predominant in Santa Helena. However, the Shannon-Weaver values observed in this study were lower than those presented by Sekine et al. (2013), which evaluated three apiaries (3.89, 3.77 and 3.60), in the counties of Ubiratã and Nova Aurora, in region Northwest and Western of Parana State, which indicates greater diversity of pollen types in these samples ( 80 types of pollen in honey samples collected monthly), although, only three apiaries were considered.

In the samples from Terra Roxa, the relatively smaller diversity (23\%) compared to those of Santa Helena, can be explained by the presence of large areas of agricultural crops, such as soybean, since, according to Newbold et al. (2015), agricultural areas have on average 30\% less biodiversity of species. Although soybeans are not a honey plant (Garibaldi et al., 2016), it appeared as dominant pollen in $35 \%$ of these samples and were present in $100 \%$ from them. This predominance in the honey samples may have occurred due to the lack of other nectar suppliers in the period evaluated in this county.

The relatively lower value of the Shannon Specialization Index (H2': 0.33 and 0.46) also indicated this greater species variety in Santa Helena. This same trend can also be confirmed when considering the proportion of monofloral honey samples ( $40 \%$ for Santa Helena and $60 \%$ for Terra Roxa). However, this index also reflecting the peculiar vegetal cover of each county, also observed in Figure 3, that some botanical species were of great importance for the constitution of honey sampled in each county: pollen type H. dulcis (grape from Japan) and type pollen G. $\max$ (soybean), presents (95\% and $100 \%$ ) and dominants pollen $(40 \%$ and $35 \%$ ), considered monofloral honey, in the samples of Santa Helena and Terra Roxa, respectively. Sereia et al. (2011) evaluated 11 samples of organic and six nonorganic honey from the region of the state between the states of Mato Grosso, São Paulo and Paraná and classified them as $41.20 \%$ of monofloral origin and the remainder polyfloral.

The results of the evenness index (J') also suggest that there is heterogeneity of the floral resources used by the bees in each study area, since they were greater than 0.5 . The samples from Terra Roxa presented lower average value of evenness $(0.58)$ in pollen types than those from Santa Helena (0.71), possibly because the plant species with many individuals, such as soy, contributed to the reduction of this value (Table 4). This information corroborating the diversity indexes $\left(\mathrm{H}^{\prime}\right)$ and authors discussed above.

The relatively high Sorensen Similarity Index (83.7), for the frequency of the pollen types found in the samples of the two studied localities, can be explained by the relative proximity between the counties, about $80.46 \mathrm{~km}$ in a straight line. Sekine et al. (2013) recorded $87 \%$ similarity from the pollen types present in samples of honey from Ubiratã and Nova Aurora, also in Western Paraná, at 27.74 km distance from each other. These results are similar to those found in the present study. Marchini et al. (2001), studying honey samples from the counties of Piracicaba and Pindamonhangaba, both in the State of São Paulo, at $225.56 \mathrm{~km}$ distance in a straight line, found a similarity index among the families of $62.68 \%$.

Another important point to be considered, regarding the similarity observed in the botanical composition between both counties, is that both are part of the reforestation programs of the Paraná River Basin 3. This botanical constitution expresses the phytogeographic characteristics of the region, since, for the restoration of the riparian forest on the banks of Lake Itaipu (Paraná River) and its tributaries, about 44 million seedlings were distributed over several years, creating an ecosystem with peculiar vegetation (Itaipu, 2017), with an abundance of grapes of Japan (H. dulcis) and Leucena (L. leucocephala).

The presence of these two pollen types and of $P$. rigida (native species), was representative in the samples from Santa Helena, and M. scabrella was important pollen types in the samples of Terra Roxa, honey bee species plant widely propagated by beekeepers in region. In relation to Eucalyptus, whose pollen was detected in significant quantities in the honey samples of both counties, it has several species of beekeeping importance, used in the reforestations in the region.

This melissopalynological information confirms ones of Camargo et al. (2014), that found, in floristic survey, greater plant diversity and greater presence of apicultural plants in Santa Helena than in Marechal Cândido Rondon, county with predominance of agriculture. The authors discussed that this greater floristic diversity allowed a greater honey production 
of the first county, although there was a greater overlap of the georeferenced apiaries areas.

According to Mensah et al. (2017), the bee plant richness in natural forests would produce diverse nutritious resources to bee colonies, at different times of the bees' foraging activities. This trend may also reflect the amount of honey produced by the counties involved in this study, $80,380 \mathrm{~kg}$ by Santa Helena and $8,500 \mathrm{~kg}$ produced by Terra Roxa (IBGE, 2015).

Sodré et al. (2008) analyzed 35 samples of honey and observed great variability, in county of Picos, in state of Piaui, region Northeast of Brazil, that has stood out in the last decade for the high production of honey. They found 36 types of pollen, distributed in 18 botanical families, and Piptadenia, M. caesalpiniiaefolia, and M. verrucosa (all LeguminosaeCaesalpinioideae) and Croton urucurana (Euphorbiaceae) as dominant pollen types.

The information obtained and discussed in this study, referring to pollen specificity and diversity, in the honey of the region, will be important for the conquest of the Denomination of Origin seal of this product by beekeepers, after further research to prove this correlation between the composition of the product and its origin phytogeographic. The importance of some plants for beekeeping in the region was discussed, so that beekeepers can conserve this flora and better plan the implantation of their apiaries.

\section{Author Contributions}

All authors were involved in designing and performing the study. All authors except F. J. wrote an initial draft of the manuscript, which D. G. then revised and finalized. F. J. assisted with data analyses and writing of the manuscript.

\section{Acknowledgements}

We thank the beekeepers associated with the Beekeeping Cooperative of the West Coast of Paraná (COOFAMEL) for the samples provided. This study was financed in part by the Coordenação de Aperfeiçoamento de Pessoal de Nível Superior - Brasil (CAPES) - Finance Code 001. We also thank the anonymous reviewers who reviewed this manuscript.

\section{References}

Abemel. (2018). Associação Brasileira de Exportadores do Mel Setor Apícola Brasileiro em Números. [2018]. Disponível em: $<$ http://brazilletsbee.com.br $>$. Acesso em 11 janeiro de 2018.

Barth, O.M. (1989). O pólen do mel brasileiro. Rio de Janeiro: Luxor, $226 \mathrm{p}$.

Behm, F., Ohe, K. \& Henrich, W. (1996). Zuverlässigkeit der Pollenanalyse von Honig. Bestimmung der Pollenhäufigkeit, Dtsch. Lebensm, 92: 183-187.

Camargo, S.C., Garcia, R.C., Feiden, A., Vasconcelos, E.S., Pires, B.G., Hartleben, A.M. \& Gremaschi, J.R. (2014). Implementation of a geographic information system
(GIS) for the planning of beekeeping in the west region of Paraná. Anais da Academia Brasileira de Ciências, 86: 955971. doi: 10.1590/0001-3765201420130278.

De Andrade, C.K., Dos Anjos, V.E., Felsner, M.L., Torres, Y.R. \& Quináia, S.P. (2014). Relationship between geographical origin and contents of $\mathrm{Pb}, \mathrm{Cd}$, and $\mathrm{Cr}$ in honey samples from the state of Paraná (Brazil) with chemometric approach. Environmental Science and Pollution Research, 21: 1237212381. doi: 10.1007/s11356-014-3175-2.

Embrapa. (2006). Empresa Brasileira de Pesquisa Agropecuária. Centro Nacional de Pesquisa de Solos. Sistema brasileiro de classificação de solos. 2.ed. Rio de Janeiro: Embrapa solos, 412p.

Erdtman, G. (1960). The acetolysis method: - a revised description. Svensk Botanisk Tidskrift, 54: 561-564.

Estevinho, L.M., Chambó, E.D., Pereira, A.P.R., Carvalho, C.A.L. \& Toledo, V.A.A. (2016). Characterization of Lavandula spp. Honey Using Multivariate Techniques. Plos One, 2: 1-15. doi: 10.1371/journal.pone.0162206.

Fagúndez, G. (2016). Botanical and geographical characterization of honeys in Diamante, Entre Ríos, Argentina. Palynology, 40: 308-321. doi: 10.1080/01916122.2015.1045994.

Garibaldi, L.A., Carvalheiro, L.G., Vaissière, B.E., GemmillHerren, B., Hipólito, J., Freitas, B. M., ... \& An, J. (2016). Mutually beneficial pollinator diversity and crop yield outcomes in small and large farms. Science, 351: 388-391. doi: 10.1126 / science.aac7287.

Hammer, Ø., Harper, D.A.T. \& Ryan, P.D. (2001). PAST: Paleontological Statistics Software Package for Education and Data Analysis. Palaeontologia Electronica 4: 1-9. Disponível em: http://palaeo-electronica.org/2001_1/past/issue1_01.htm (Acessado 23 Maio de 2010).

IBGE - Instituto Brasileiro De Geografia E Estatística. Produção Pecuária Municipal (2015). Disponível em: <https://sidra. ibge.gov.br>. Acesso em: 24 de julho de 2017.

IBGE - Instituto Brasileiro De Geografia E Estatística. Pesquisa da Pecuária Nacional. (2016). Disponível em: <https://sidra.ibge. gov.br/tabela/74\#resultado> Acesso em: 09 de fevereiro de 2018.

INPI. Instituto Nacional Da Propriedade Industrial. (2017). Revista da Propriedade Industrial No 242604 de julho de 2017, Indicações Geográficas Seção IV Disponível em: http:// revistas.inpi.gov.br/rpi/. Acesso em: 04 de julho de 2017.

ITAIPU. Gestão por bacias: territorialidade definida pela própria natureza. (2017). Disponível em: <http://www. cultivandoaguaboa.com.br/acao/nivel-1/gestao-por-bacias>. Acesso em: 02 de abril de 2018.

Kaškonienè, V. \& Venskutonis, P.R. (2010). Floral markers in honey of various botanical and geographic origins: a review. Comprehensive Reviews in Food Science and Food Safety, 9: 620-634. doi: 10.1111/j.1541-4337.2010.00130.x. 
Köppen, W. (1948). Climatologia; versão para o espanhol de Pedro R. Hendrichs Pérez. México, Fundo de Cultura Econômica. 466p.

Kuchla, M., Araújo, M.D.M., Soares A.F., Quináia, S.P. \& Felsner, M.L. (2015). Classification of wild honeys of different mesoregions from Paraná State, Brazil, by principal component analysis. Revista Virtual de Química, 7: 23012313. doi: 10.5935/1984-6835.20150137.

Legendre, L. \& Legendre, P. (1984). Ecologie numerique. 2. ed. Paris: Masson. 335p.

Louveaux, J., Maurizio, A. \& Vorwohl, G. (1978). Methods of melissopalynology. Bee world, 59: 139-157. doi: 10.10 80/0005772X.1978.11097714.

Marchini, L.C., Moreti, A.C.C.C., Teixeira, E.W., Silva, E.D., Rodrigues, R.T. \& Souza, V.C. (2001). Plants visited by africanized honey bees in two localities of the state of São Paulo. Scientia Agricola, 58: 413-420. doi: 10.1590/S010390162001000200028.

Marchini, L.C,. Sodré, G.S. \& Moreti, A.C.C.C. (2004). Mel brasileiro: composição e normas. Ribeirão Preto: A.S. Pinto, $111 \mathrm{p}$.

Martins, A.C.L., Rêgo, M.M.C., Carreira, L.M.M. \& Albuquerque, P.M.C. (2011). Espectro polínico de mel de tiúba (Melipona fasciculata Smith, 1854, Hymenoptera, Apidae). Acta Amazonica, 41: 183-190. doi: 10.1590/S004459672011000200001.

Mensah, S., Veldtman, R. \& Seifert, T. (2017). Potential supply of floral resources to managed honey bees in natural mistbelt forests. Journal of Environmental Management, 189: 160-167. doi: 10.1016/j.jenvman.2016.12.033.

Moraes, F.J., Garcia, R.C., Vasconcelos, E., Camargo, S.C., Pires, B.G., Hartleben, A.M. \& Gremaschi, J.R. (2014). Physicochemical parameters of honey from samples from africanized honeybees in Santa Helena and Terra Roxa counties (PR). Arquivo Brasileiro de Medicina Veterinária e Zootecnia, 66: 1269-1275. doi: 10.1590/1678-6865.

Newbold, T., Hudson, L.N., Hill, S.L., Contu, S., Lysenko, I., Senior, R.A. \& Day, J. (2015). Global effects of land use on local terrestrial biodiversity. Nature, 520: 45-50. doi: 10.1038 /nature 14324 .

Osterkamp, I.C. \& Jasper, A. (2013). Análise palinológica em méis da região do Vale do Taquari, Rio Grande do Sul, Brasil: Ferramenta para a definição de origem botânica. Destaques Acadêmicos, 5: 117-125.

Ostrovski, D. (2014). Itaipu Binacional: Implantação, Reflexos Socioambientais E Territoriais. Revista Percurso, 6: 3-26. doi: 10.4025/revpercurso.v6i2.23290.

Paula, M. F., Santos, A.J.D., Silva, J.C.G.L.D., Timofeiczyk Junior, R. \& Hoeflich, V.A. (2015). Dynamics of the Brazilian
Exports of Natural Honey Between 2000 and 2011. Floresta e Ambiente, 22: 231-238. doi: 10.1590/2179-8087.062713.

Pielou, E.C. (1975). Ecological diversity. New York: John Willey, 165p. doi: 10.4319/lo.1977.22.1.0174b.

Pielou, E.C. (1966). Species-diversity and pattern-diversity in the study of ecological succession. Journal of Theoretical Biology, 10: 370-383. doi: 10.1016/0022-5193(66)90133-0.

R Core Team. R (2014). A Language and Environment for Statistical Computing. R Foundation for Statistical Computing: Vienna, 2014. Available online: <http://www.R-project.org/> accessed on 20 October 2017.

Ramírez-Arriaga, E., Navarro-Calvo, L.A. \& Díaz-Carbajal, E. (2011). Botanical characterization of Mexican honeys from a subtropical region (Oaxaca) based on pollen analysis. Grana, 50: 40-54. doi: 10.1080/00173134.2010.537767.

Sekine, E.S., Toledo, V. A., Caxambu, M. G., Chmura, S., Takashiba, E. H., Sereia, M. J. \& Moreti, A.C.C.C. (2013). Melliferous flora and pollen characterization of honey samples of Apis mellifera L., 1758 in apiaries in the counties of Ubiratã and Nova Aurora, PR. Anais da Academia Brasileira de Ciências, 85: 307-326. doi: 10.1590/S000137652013005000017.

Sekine, E.S., Takashiba, E.H., Bueno, R.O., Bueno, P.A.A., Caxambu, M.G., Sereia, M.J., Marchini, L.C., Moreti, A.C.C.C. \& Toledo, V. A.A. (2019). Floral origin and physical and chemical characteristics of honey from Africanized bees in apiaries of Ubiratã and Nova Aurora, State of Paraná. Sociobiology, 66: 126-135. doi: 10.13102/ sociobiology.v66i1.3385

Sereia, M.J., Alves, E.M., Toledo, V.A., Marchini, L.C., Sekine, E.S., Faquinello, P. \& Moreti, A.C. (2011). Physicochemical characteristics and pollen spectra of organic and non-organic honey samples of Apis mellifera L. Anais da Academia Brasileira de Ciências, 83: 1077-1090. doi: 10. 1590/S0001-3765201100030002.

Shannon C.E. \& Weaver W. (1949). The Mathematical Theory of Communication University of Illinois Press Urbana Google Scholar.

Sodré, G S., Marchini, L.C., Moreti, A.C.C.C. \& Carvalho, C.A.L. (2008). Tipos polínicos encontrados em amostras de méis de Apis mellifera em Picos, Estado do Piauí. Ciência Rural, 38: 39-842. doi: 10.1590/S0103-84782008000300043.

Song, X.Y., Yao, Y.F. \& Yang, W.D. (2012). Pollen analysis of natural honeys from the central region of Shanxi, North China. PloS One, 7: e49545. doi: 10.1371/journal.pone.0049545.

Willers, E.M., Alves, L.R. \& De Souza, E.B.C. (2016). Dinâmicas territoriais no município de Terra Roxa-PR (1970-2007). Interações, 1: 71-80 doi: 10.1590/S151870122010000100007 . 